\title{
Gendered Representations of Apartheid: The Women's Jail Museum at Constitution Hill
}

\author{
Stephanie Bonnes*, Janet Jacobs**
}

\begin{abstract}
This article examines the ways in which women are represented and remembered at The Women's Jail at Constitution Hill museum, a former women's jail that was used to incarcerate women during apartheid in Johannesburg, South Africa. Based on fieldwork at the museum, this study examines how the memory of the former prisoners and of the apartheid regime is shaped and narrated at this site. Situating our analysis within the context of the collective memory of apartheid, we examine how the museum uses artifacts and objects to depict both the specific forms of gendered dehumanization that women experienced at the jail, as well as their journeys to incarceration as a result of discriminatory apartheid laws. We also examine the absence of torture memory and references to hierarchical structures and interactions within the jail itself, noting that these were important dynamics of prison life that are not represented in the museum. This research presents a content and visual analysis of how the use of images and artifacts may illuminate and/or silence specific memories of degradation and humiliation in a museum space.
\end{abstract}

Key Words: Collective Memory, Museums, Representation, South Africa, Apartheid Memorialization, Gender and Memorialization

\section{Introduction}

In recent decades the study of collective memory has been established as an important area of research that examines nationalist projects of memorialization that seek to preserve, reproduce and commemorate a difficult and tragic past (Olick, Vinitzky-Seroussi, and Levy 2011; Young 1993). In South Africa such projects are evident in the construction of museums and memorials to apartheid that today provide a social mechanism for the recollection of social injustice and the power of resistance in the face of human suffering and violent political oppression (Longair 2013; McEachern 1998; Nanda 2004; Van Der Watt 2005). Among the museum sites that have been dedicated to the memory of apartheid is the former Women's Jail at Constitution Hill. Because of its focus on women in the apartheid struggle, this museum holds a unique place in South African memorial culture, highlighting the treatment of women prisoners and the importance of women as social actors in movements for social change. While women were actively involved in the struggle against the apartheid regime, including being jailed and tortured for their opposition, the majority of studies analyzing museums and memorials in South Africa include little reference to women's roles or the types of gendered violence to which women were subjected (Coombes 2003, 2011; McAlister 2013; Miller 2011).

A number of previous studies, however, have investigated the collective memory of women prisoners as the memory of incarceration is memorialized at the Women's Jail. In this regard, prior research found that the museum is distinct from other apartheid museums in both its curatorial process and its exhibits (Coombes 2011; McAlister 2013). McAlister thus states 'I find the personal and fragmented objects assembled in the Women's Jail to be the inverse of the conventionally "comprehensive" and "linear" museum collections' (2013: 7). Further, 
in discussing the exhibits in the museum, previous researchers have focused on the motifs of women's degradation that the museum highlights (Coombes 2011: McAlister 2013) Building on the existing research on the Women's Jail, our study considers the varied and diverse ways in which Black women are remembered in the memorial space and the gendered representations that illuminate Black women's dehumanization under apartheid. Based on extensive field work at the museum site, the findings of the research suggest four motifs of gendered memory that have yet to be fully elaborated in the existing work on the women's musuem on Constitution Hill. These themes, which are central to the exhibits and installations of the museum, are: 1) Women's journeys to incarceration; 2) women's humiliation and degradation within the jail; 3 ) racial privilege within the incarceration structure; and 4) the absence of atrocity memory. Within these frames of memory, we examine the structures that the museum employs to represent and convey the meanings of the past, including photographs, material artifacts, art installations and audio recordings.

Our research contributes to the literature on South African collective memory in a number of important ways. First, by investigating the site of Black women's incarceration as a space of national memory; second by exploring the representation of Black women's treatment and dehumanization within the larger context of apartheid history and racialized hierarchies; and third by problematizing the role of torture memory within a gendered analysis of women's victimization. Further, we argue that the museum's focus on women's arrest, dehumanization, and humiliation contributes to a greater understanding of how apartheid functioned within a gendered and racialized system of oppression. We begin with a description of the museum site and the curatorial process for selecting and creating the exhibits that comprise this museum space.

\section{The Museum at Constitutional Hill: History and Transformation}

The history of Constitutional Hill begins under the regime of Paul Kruger, the president of the Boer Republic, who in 1893 built a fort (today known as the Old Fort) to monitor, control and later imprison the large influx of foreign miners who moved to Johannesburg in the late $1800 \mathrm{~s}$ during the mining rush (Gevisser and Nuttall 2004: 509; Madikida et al. 2008: 17). The Boers built a jail in the original fort that was used to imprison both petty criminals and those perceived as a threat to their interests (Van der Merwe 2013: 577). Tensions between the Boers and the British in Johannesburg continued to build throughout the 1890s, culminating in the second Anglo-Boer war that started in 1899. During this time, the Boers used the fort to monitor the movement of the British. However, when the British took control of Johannesburg in 1900, they also took the Old Fort where they used the space to imprison, force surrender, and execute Afrikaners (Gevisser and Nuttall 2004: 510; Madikida et al. 2008: 18; Van der Merwe 2013: 577).

After the second Anglo-Boer War ended in 1902, the fort complex was used as a prison and remained the main site of incarceration in the city of Johannesburg until 1983. White male prisoners were held in the Old Fort buildings and the British built new sections to the jail. Between 1904 and 1910, the British added Sections Four and Five which included the awaiting trial block, the section of the jail reserved for Black South Africans, and the Women's Jail that housed both Black and White prisoners in segregated sections (King and Flynn 2012: 66). The jails were closed in 1983 after which some of the buildings were used for other purposes, while others were abandoned. During this time, part of the Women's Jail was torn down while the remainder of the building was used by the Johannesburg City Security Department (King and Flynn 2012: 67). In 1996, the judges of the post-apartheid Constitutional Court decided that the former prisons would be converted into the new home of the Constitutional Court. This decision was based partially on the central location of the space. However, the other reason for housing the Constitutional Court here was symbolic: to transform a former place of apartheid oppression and terror into a site of justice, freedom, and equality (Madikida et al. 2008: 18; Simigiannis 2012: 23). Notably, the awaiting trial block and some sections of the Women's Jail were removed to build the Constitutional Court and the building that today houses the Commission on Gender Equality. Additionally, it was decided that the other structures on Constitution Hill would be preserved to memorialize former prisoners. The Women's Jail, which opened as a museum in 2005 , is one such site. 
As a site of remembrance, the Women's Jail museum developed in conjunction with the Mapping Memory project $^{1}$, an initiative to collect prisoner testimonies for the creation of national apartheid museums and memorials. In an attempt to facilitate 'public ownership of the space,' a number of former inmates were invited back to the site to collaborate with curators in workshops and to participate in other memory initiatives (Madikida et al. 2008: 20; Simigiannis 2012: 24). The former prisoners were encouraged to share their memories and to portray their recollections in artwork, written accounts, and oral testimonies (Segal et al. 2006: 3-4; Simigiannis 2012: 24). Additionally, material for the museum was gathered from former prison wardresses (guards) who also participated in the project (Segal et al. 2006:1). In evaluating the curatorial process, it is important to note that not all prisoners participated in the workshops held at the jail. Because a list of former prisoners did not exist, the process of locating women participants was difficult (Madikida et al. 2008:20). In this regard, political prisoners were more easily identified, as compared to women who were arrested for prostitution and other non-political crimes under the discriminatory apartheid laws. Accordingly, many of the narratives in the museum are situated within the history and experiences of the political prisoner population.

At present, the site makes clear that the exhibits in the space were created primarily through collaboration with former prisoners. For example, the ticket office and the walkway to the Women's Jail displays a large collage that states: 'The Exhibition Process: Ex-Prisoners Return to Tell Their Stories.' The collage has five large images of women who were once imprisoned in the jail. Thus, before one enters the site itself, it is defined as a space where the former prisoners, now free, will lead the visitor through this terrible past. One of the images in this collage includes a photograph of three women laughing in the courtyard of the jail, imagery that denotes a sense of solidarity and connection, despite the harsh conditions of prison life. Taken together, these visual texts suggest that the Women's Jail is a site of transformation, where women who were once imprisoned can now shape the memory of their experiences and of their oppression. As a site that former prisoners have reclaimed, the museum has been commended for its unique creation of exhibits that include the voices, concerns, and objects of the former detainees (Coombes 2011; McAlister 2013). Furthermore, this site holds a noteworthy place within the evolution of museums to violence and oppression because of its relationship specifically to women's persecution and suffering under regimes of terror.

Finally, the jail museum is situated next to a building that houses the new Commission on Gender Equality. When visiting the jail memorial, the tour guide points out that the Commission stands above the courtyard where gender oppression occurred. A nearby plaque is dedicated to 'Women in the First National Assembly of the Republic of South Africa 1994-1999: Women's Development Foundation celebrating women's contribution to non-sexist, non-racial, and democratic South Africa.' This plaque, along with the reference to the jail and its history of gender persecution, reminds visitors both of the treatment of women under apartheid and women's on-going role in the struggle for equality.

\section{Methodology and Research Approaches}

The research at the museum was conducted in 2014. Data collection at the site included participant observation in the museum spaces and the use of photographic data gathering to create a visual archive for the purposes of interpretive analysis. This methodological approach is situated within the growing field of visual sociology and collective memory wherein the use of photography as a data gathering tool has grown in importance (Williams 2015). Fieldwork at the museum thus included touring the facility, photographing the installations, and observing the visitor culture in the museum space. During the research gathering phase, field notes were taken at the site to help contextualize the images and visual frameworks that were being recorded in the photographic data. In using photography as a research tool, attention was paid to the importance of inclusivity in the selection of photographic subject matter within the museum. To this end, all of the installations were photographed, along with museum signage and explanatory texts. The photographic archive on which the analysis is based therefore is extensive and representative of the memorial narratives within the Women's Jail.

Altogether, we analyzed 300 photographs that were taken at the multiple exhibits that 
comprise the museum installations. We conducted a content analysis of the images. We wrote analytic and integrative memos based on patterns that emerged from examining the photographs of the exhibits to develop themes for analysis (Emerson et al. 1995; Lofland, Snow, Anderson and Lofland 2006). In our coding and analysis, we paid particular attention to how the experiences of women were represented in the jail and how their memories of political persecution and oppression under apartheid were portrayed in the visual and textual narratives of imprisonment and activism. To this end, we examined the use of material culture (e.g. clothing and prison artifacts) and the recorded and textual narratives that recall and recreate the prison experience. In addition, we investigated the ways in which the memory of incarceration was constructed around the extant prison site, including the use of prison cells as exhibition and narrative spaces. Paying attention to the notion that 'Every politics of memory simultaneously urges us to remember some things, while prompting us, paradoxically, to actively forget others' (Du Toit 2016: 33) we not only examined how the memories that were present in the site were represented, but we looked at the memories that were missing from the space as well.

While the jail housed both Black and White detainees who were incarcerated for political and non-political 'crimes', they were housed in different buildings of the jail, received drastically different treatment, and hardly interacted with one another. Therefore, the focus of this research is on the collective memory of Black women who were incarcerated in the Black section of the jail. Accordingly, the study is centered on those installations that comprise the Black section of the Women's Jail. Under apartheid segregation, the White prisoner's section was more spacious and better maintained. By comparison, the Black women's section was over-crowded and contained smaller isolated cells. As the findings of the research will show, the memorialization of Black women prisoners reveals the ways in which the treatment of incarcerated Black women was linked to the national apartheid project that actively dehumanized Black South Africans.

More specifically, the findings address how the museum represents the memory of women's resistance and incarceration through stories of arrest and imprisonment and through installations that make visible the everyday lives of Black women under the apartheid regime. In the analysis which follows, we explore how the memory of degradation and humiliation is conveyed within the structural dynamics of jail culture, focusing on themes of gendered dehumanization and indignity. In addition, our findings also consider the absence of memory within the museum narratives, particularly with respect to the hierarchical structures of the prison system and the use of torture. We begin our analysis with a discussion of the installations that focus on the experiences of arrest and incarceration.

\section{Imprisoned Memory: Incarceration and Political Discrimination}

It should be noted that many of the 'criminal' prisoners at the women's jail were arrested under the oppressive apartheid laws that restricted and confined the daily lives of people of color in South Africa (Gevisser and Nuttall 2004: 515). Madikida et al. (2008) argue that because of this, the line between criminal and political prisoner at the women's jail was not clear. To understand how this was the case it is important to discuss the racist ideology that become codified and institutionalized in South Africa through the development and implementation of over 200 apartheid laws and amendments concerning rights based on race (Derrida 1985). These laws prohibited racial mixing in education, occupation, sexual and romantic partnerships, and residence and were all punishable with incarceration. Under apartheid, race determined where people lived, where they worked, what kind of work they were allowed to do, what type of education they received, which public facilities they could access, who they could associate with, who they could marry, as well as what they had the 'right' to do. In order to monitor and enforce these laws, the Population Registration Act was formed in 1950. This act led to the creation of a national register where every person's race was recorded and listed on his/her identity documents. The Apartheid government then claimed that 'innate' racial inferiority of Black people to White people served to validate that they receive different and inferior access to facilities, education, jobs and property (Tihanyi 2007). Accusing a person of color of breaking an apartheid law, no matter how small, often resulted in punishment for the person of color. Thus, the structural inequality laid out by the apartheid government was lived out in daily, 
interpersonal exchanges. The exhibits at the Women's Jail highlight the gendered aspects of the discriminatory apartheid laws and extreme political oppression that lead to Black women's incarceration.

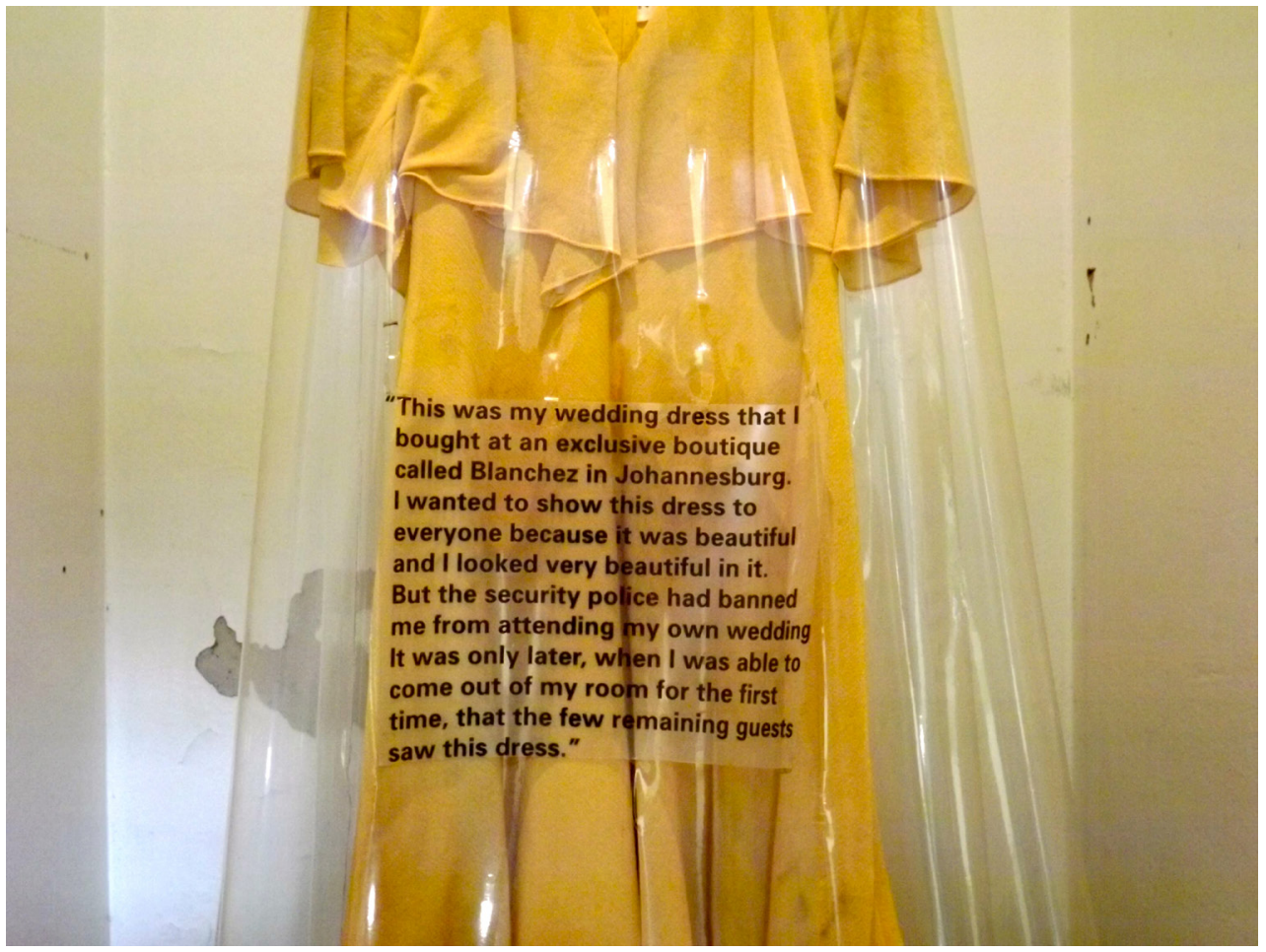

Fig 1. The Wedding Dress

As a historical marker of political persecution, the jail represents a past in which Black women were routinely arrested for ordinary actions deemed illegal or coded as 'political activity' under discriminatory apartheid laws. The installation that highlights the unequal apartheid laws or the political activities that lead to incarceration is housed in six isolation cells that have been reconstructed as exhibition spaces. Each cell tells the story of a former prisoner whose testimony has been videotaped and is repeatedly played on a small monitor that is mounted from the ceiling in the narrow and confining cell. Upon entering the cell, the visitor hears the voice and sees a video of the former prisoner as she describes her arrest and the types of treatment to which she was subjected during the incarceration process. As the former prisoner narrates her story, she also describes the artifacts that have been placed on display in the small room, objects such as clothing and personal belongings that give each prisoner a unique and distinctive identity. In the cell that is dedicated to Yvonne Ntonto Mhlauli, for example, the exhibit includes the clothes she was wearing when she was arrested. In her narrative, she explains the significance of these garments which, because of their high quality, led to her arrest as a prostitute, the police assuming that the clothes were 'too nice' for an ordinary law abiding Black woman. Her nice clothing, and the assumptions that the police officers made about that clothing, lead the police to arrest her under the 'Immorality Amendment Act.' In an adjacent cell, that of the former prisoner Nikiwe Deborah Matshoba, a wedding dress is displayed beneath a plastic shroud on which the following text has been overlaid (Figure 1):

This was my wedding dress that I bought at an exclusive boutique called Blanchez in Johannesburg. I wanted to show this dress to everyone because it was beautiful and I looked very beautiful in it. But the security police had banned me from 
attending my own wedding and it was only later, when I was able to come out of my room for the first time, that the few remaining guests saw this dress.

Matshoba was an active resistor of apartheid and was appointed the literacy director of the South African Students' Organization (SASO) in 1973. She was banned from attending her own wedding as a result of her arrest record and her political involvement with SASO. As the signage quoted above suggests, the gendered and ceremonial specific clothing is intended to highlight the prisoner's domestic life outside her incarceration and her oppressive treatment under apartheid. Invoking the memory of marriage and a missed wedding ceremony rather than her activism, the dress represents the former prisoner as an ordinary Black woman who was barred from this important life cycle event. Because her activism and resistance are not described, the emphasis in this installation is on how apartheid shaped the every day life of all Black South Africans. By emphasizing how Matshoba was banned from attending her wedding and how Mhlauli was arrested for wearing nice clothing, these exhibits, rather than focus on political resistance, highlight how apartheid politicized the daily life of Black South Africans more extensively.

Taken together the videos and the clothing in these two installations situate the memory of the women detainees in two frames, one that memorializes their arrest and loss of rights and the other that reifies their domesticity and the gendered forms of discrimination that led to incarceration. The cell itself is small, cramped, and poorly lit, further commemorating the conditions under which women were taken into custody and were frequently punished by being placed into isolation. Other testimonies, which are featured outside the cells, make it clear that isolation was among 'the cruelest' forms of punishment.

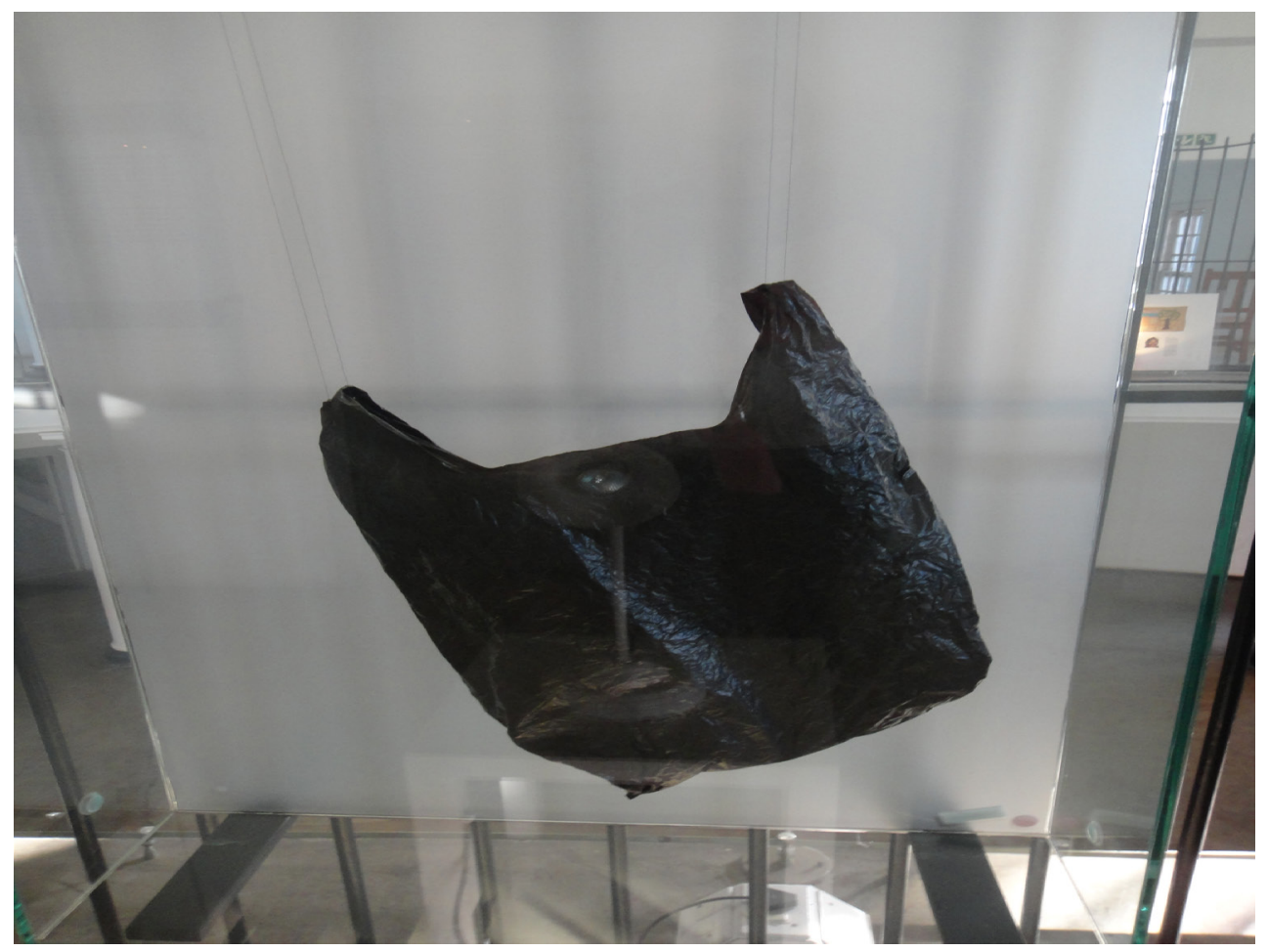

Fig 2. The Shopping Bag

In addition to the isolation cells, two other displays use artifacts and objects to recall the memory of how women came to be incarcerated. In these installations, housed on the second floor of 


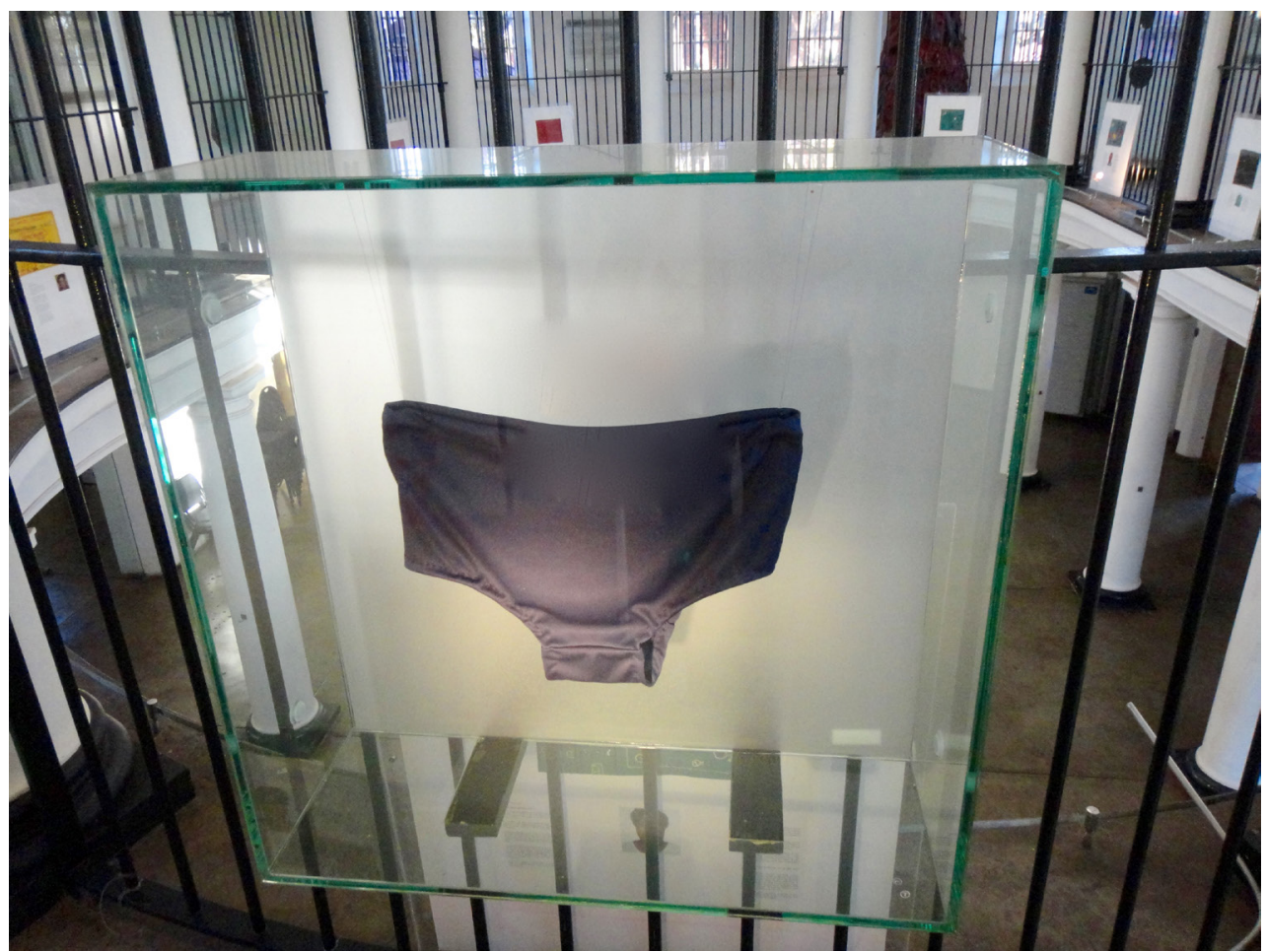

Fig 3. The Panties

the museum, a passbook and a plastic shopping bag (Figure 2) symbolize the discriminatory laws that led to the imprisonment of many Black women. The pass book, a remnant of the apartheid regime, serves as a symbol of discrimination and persecution. Under apartheid, Black people in South Africa were restricted to certain areas and had to carry their pass book at all times (Waetjen 1999). As a form of continued harassment, many Black women were arrested on pass book violations while going about their daily routines. On exhibit is the torn and well worn passbook of a prisoner whose faded picture places this history of discrimination in the distant past, even while the memories that are recreated in the jail provide a visual and emotional context through which to re-experience apartheid in the present.

The museum reflects the gendered nature of arrest that existed during apartheid South Africa. While Black men and women were routinely arrested for passbook violations, the shopping bag on display represents a gendered pathway to arrest. Encased within a plexi glass frame, the worn Black shopping bag recalls the risks that Black women faced in their every day domestic lives when a routine shopping trip might lead to imprisonment. The simplicity of the display illustrates how commonplace arrests like this were for women of color living under the apartheid regime. The testimony that accompanies the installation positions the ordinary bag within a narrative of danger:

My grandmother had taught us to say goodbye every time we left home, because we never knew if we would come back or not. We used to say, "If you don't see me, check for me at number Four" (Nolundi Ntamo, a former prisoner). 


\section{Memories of Humiliation: Imprisonment and Daily Life}

The experiences of daily life in the jail are primarily represented in the exhibits that are housed on the second floor of the museum. Here an atrium contains artifacts and written texts that relate to the lives both of former prisoners and their guards. The many objects that have been placed on display have varied meanings and are emblematic of the most degrading and humiliating aspects of prison life. Unlike the isolation cell installations, the narratives of daily life do not include recorded testimonies of the former prisoners but rely on objects such as underwear and 'punishment buckets' to tell the stories of imprisonment. Here three red buckets ['rooi emmers'] recall the punitive ways in which food was used to taunt the prisoners, as the signage in the installation explains: 'For minor misdemeanors prisoners were deprived of their meals and made to stand next to the three [red buckets] in the large courtyard. From there they could see and smell the meals that the other prisoners received.' While this exhibit emphasizes deprivation of food as discussed by Coombes (2011), it also conveys the types of humiliation that women suffered at the hands of a punitive penal system. Through the imagery of the buckets and the texts that describe their use as an object of punishment, the visitor is reminded of how the targeted women were forced to stand apart from, but in full view, of other prisoners who were eating. The public aspect of this meal time punishment was intended to humiliate and shame the former prisoners, while at the same time depriving them of food. Similarly, display objects such as black panties and sanitary napkins represent gendered forms of both deprivation and humiliation in the collective memory of the jail.

\section{Menstruation, Dehumanization and the Humiliated Body}

Through apartheid, the government formalized the institutionalized racism that had dominated South Africa for centuries through colonization. The apartheid narrative was focused on hierarchical racial categorizations (White, Indian/Asian, Coloured and Bantu/African) and political and social rights were granted based on these categorizations (Posel 2010). While there was a hierarchy of race in South Africa (that included those of mixed races), rights and policies were based on the binary of White and Black-Black was considered inferior and was defined in opposition to the 'superior' White (Posel 2010). While White people were considered intelligent, sophisticated, and innovative, Black people were considered stupid, barbaric, violent and naturally suited to menial labor (More 2014). This racist ideology became further institutionalized through laws that granted voting, property and even citizenship rights based on race, denying Black people access to these things. Race thus took on a totalizing effect, as racial categories became the main way that individuals' lives were structured and understood (Motsemme 2002; Posel 2010). Apartheid ideology used biological racism and pseudo-science to 'confirm' and justify the inferiority of Black people and the superiority of White people (Koorts 2013:557). This racist idea that Black people were subhuman and inferior to White people was so pervasive and had such severe psychological effects on people of color that the Black Consciousness Movement in South Africa identified defining Blackness outside of an apartheid gaze as central to resistance (Gibson 2008; Hook 2011). Thus, re-humanization of Black people was central to the resistance to apartheid. Stephen Biko, a prominent activist in the struggle against apartheid who played a key role in developing the Black Consciousness Movement, argued that for Black people to be free in South Africa they had to be psychologically liberated and physically liberated (Biko, 2005). Indeed, much of the Black resistance to apartheid was focused on re-evaluating blackness and challenging the apartheid categorizations. Therefore, it is not surprising that correctional facilities under apartheid focused on re-affirming these categorizations and solidifying the notion that Black people were inferior to White people inside of these spaces. As part of this process, jailers and wardens treated Black prisoners as less than human, by demeaning them, depriving them of basic necessities, treating them like animals, and through torture (Graybill 2001:7).

The treatment of Black prisoners as 'other' was intensified in jails and prisons. Places of incarceration were segregated by race and the apartheid racial hierarchal categorizations operated in these spaces (Gevisser \& Nuttall 2004; Pogrund 2000). White people, being at the upper end of the hierarchy, received more and better food than Coloured, Indian and Black prisoners. Black prisoners, being on the lower end of the hierarchy, received the least 
amount and the worst food rations. Additionally, treatment of prisoners and benefits given to prisoners were racially based. At the Women's Jail at Constitution Hill, White women and Black women were imprisoned in separate sections of the jail. The White women were held in larger rooms, while Black women were held in over-crowded group cells or in small isolation cells. White women were given amenities, such as sanitary pads, shoes and panties. These same amenities were deliberately withheld from Black women with the intention to degrade and dehumanize them. Thus, gendered forms of deprivation and dehumanization were perpetrated against Black women under the apartheid regime. One important example of this historical and de-humanizing treatment of Black women prisoners is found in the installations that focus on narratives of menstruation to illustrate the humiliations and indignities that women prisoners suffered. One part of the exhibition, entitled 'Panties,' features a pair of black underwear (figure 3 ) that represents the withholding of under garments from Black prisoners (but not from White prisoners) and the shame that they experienced, especially during menstruation. This seemingly unremarkable piece of clothing is contextualized by exhibit testimony in which prisoners express their shock at the sight of menstruating inmates who had been deprived of undergarments:

As the prisoners were polishing the floor, we saw that they didn't have panties. Somebody would be kneeling down to polish the floor and the sanitary pad would just drop out.

Juxtaposed against this installation, a second exhibit further embeds the image of the menstruating body into the visitor's consciousness. This installation features a solitary white cloth sanitary pad (figure 4), the inclusion of which is explained by the following interpretative panel:

To humiliate prisoners wardresses did not issue prison shoes or panties. Long-term Black prisoners were issued with three pads with loops. When the pads perished, they were issued with a further three. Short-term Black prisoners were given two pads without loops. These had to be handed in after each use.

To the right side of this text, three quotes, two from former prisoners and one from a former White wardress, contextualizes the humiliations that the pad represents:

'We used to call them manhole covers.' Theresa Swanepoel, White wardress 1980

'You didn't just get a pad. You had to prove you were bleeding by showing them.' Palesa Musa, prisoner 1981

'We were not allowed panties and we had to hold this pad between our legs. If it fell down, we'd get a flap (hit). But then we got advice from those who had been here for long to hold it with shoelaces that were stolen from storerooms. Pads used to have loops and that's where you inserted the shoelaces and tied them around your waist.' Bella Blamini, Prisoner 1973

The quoted texts highlight not only the humiliation of the imprisoned women but their gendered dehumanization as well. In this exhibit space, the subtext of the bleeding female body is invoked both by the singular image of the sanitary pad and by testimonies that recall images of women desperately trying to control the flow of blood without the aid of underwear or other supportive garments. On another museum sign nearby, a reference to Winnie Mandala's, who was imprisoned at the jail, confrontation with the prison administration over the lack of panties further suggests the loss of dignity and humanity that the women suffered: 'Winnie confronted the lieutenant herself, saying that these people were not animals, they were human beings. And even if they were in jail, they still needed their dignity.' Given the taboos surrounding menstruation and the cultural stigmas attached to women's blood, this exhibit is bold both in its symbolism and its narrative and clearly documents the gendered forms of deprivation, humiliation, and dehumanization women experienced in the jail.

With the incorporation of menstruation memory into the Jail's history, the museum is a reminder of the ways in which menstruation, in particular, was a gendered form of humiliation that was used against political activists. In this regard, the Truth and Reconciliation Commission 
(TRC), which held special hearings on women under apartheid, documented how menstruation was used specifically to control women's bodies in captivity, as the following account from Joyce Sikhakhane Ranken, a former prisoner at Pretoria Central, explains:

As woman you dreaded the commencement of your menstrual period, because it became so public under the notice of your interrogator, who were all Afrikaner males. You had to ask them for sanitary pads. With your menstrual flow they made you stand untenably as punishment. The feel and smell of the sticky blood as a reminder of eminent slaughter at the hands of your torturers. One other woman, Lulu Gwala, in 1976 was given no pads. She wrapped herself in a blanket that absorbed the blood and made her sticky and smelly (Testimony of Joyce Sikhakhane Ranken, transcript of Johannesburg Women's Hearing, 1997).

As this and other TRC testimony reveals, the treatment of Black prisoners around menstruation was intended to dehumanize and shame women activists, reinforcing their degraded status within apartheid society (Graybill 2001: 7). In this regard, the sanitary pad, as an embodied artifact, becomes the signifier of a particular kind of gendered inhumanity. The exhibit in the museum is thus a starting place from which to commemorate this past, situating the prison policies on menstruation within the larger framework of Black women's inhumane treatment.

\section{Invisible and Absent Memory: Racial Hierarchies, Torture and the Missing Texts of Remembrance}

Thus far the analysis has considered the themes of memory that have been constructed around the experiences leading to incarceration and the dehumanizing aspects of prison life. While these installations contribute significantly to the preservation of specific types of gendered memory, our research also reveals that certain other themes have been overlooked, repressed or forgotten in this rendering of a terrible past. In particular, we have identified two areas of collective memory that remain invisible within this museum context. The first is the complexities around structural and racial hierarchies within the prison system and the second is the absence of representations that recall the pervasive use of torture in this landscape of terror.

\section{Apartheid Memory and Hierarchies within the Prison System}

Prior research on museums and memorials to apartheid has noted the reductionist narrative surrounding race in those spaces (Crysler 2006: 28). In this narrative the history of apartheid in South Africa is frequently conveyed through portrayals of racial oppression that emphasize the importance of the Black/White dichotomy to the exclusion of more nuanced understandings of racial strife and color-based racial privilege. Within these narrative texts, the stories of the past are told through a bifurcated lens in which all victims are Black and all perpetrators are White (Crysler 2006: 28). In keeping with this theme of racial dichotomy, the Women's Jail at Constitution Hill highlights Black women as victims and White women as perpetrators. This is illustrated by the installation on the second floor atrium that centers on the racialized culture of the wardresses (guards) within the jail. The text on display titled 'Race and Rank' describes how Black wardresses were paid much less than White wardresses and how they were treated poorly. A chair used by the wardresses within the prison invokes the difference in working conditions that favored White guards (Figure 5). The chair helps tell the story of how White wardresses would sit down and order the Black wardresses to do all of the work. The text accompanying the chair explains that Black wardresses were not permitted to sit during the day, highlighting the testimony of Linda Xamesi, a Black wardress, who explains: 'We had to stand all the time. We should stand from 7am to 7pm.'

The stand alone object of the chair, along with the accompanying text, invokes the memory of the deprivation that Black wardresses suffered within the apartheid prison system, illuminating the inequalities that permeated the structural relations of the prison administration. In this way the chair, as an artifact of memory, allows for the re-imagining of the exploited Black wardress whose power and authority within the jail setting was circumscribed by the racial hierarchy. Further, the texts that accompany this exhibit also point out the solidarity between 
Black wardresses and Black prisoners. Here the quoted material notes that Black prisoners, who observed that the Black wardresses were forced to stand all day, would bring the guards chairs to sit on, as Xamesi's testimony explains, 'We would get some assistance from the political prisoners who were locked in isolation-people like Sis Debs, Winnie, and others. They gave us chairs to sit on because they felt sympathy for us.'

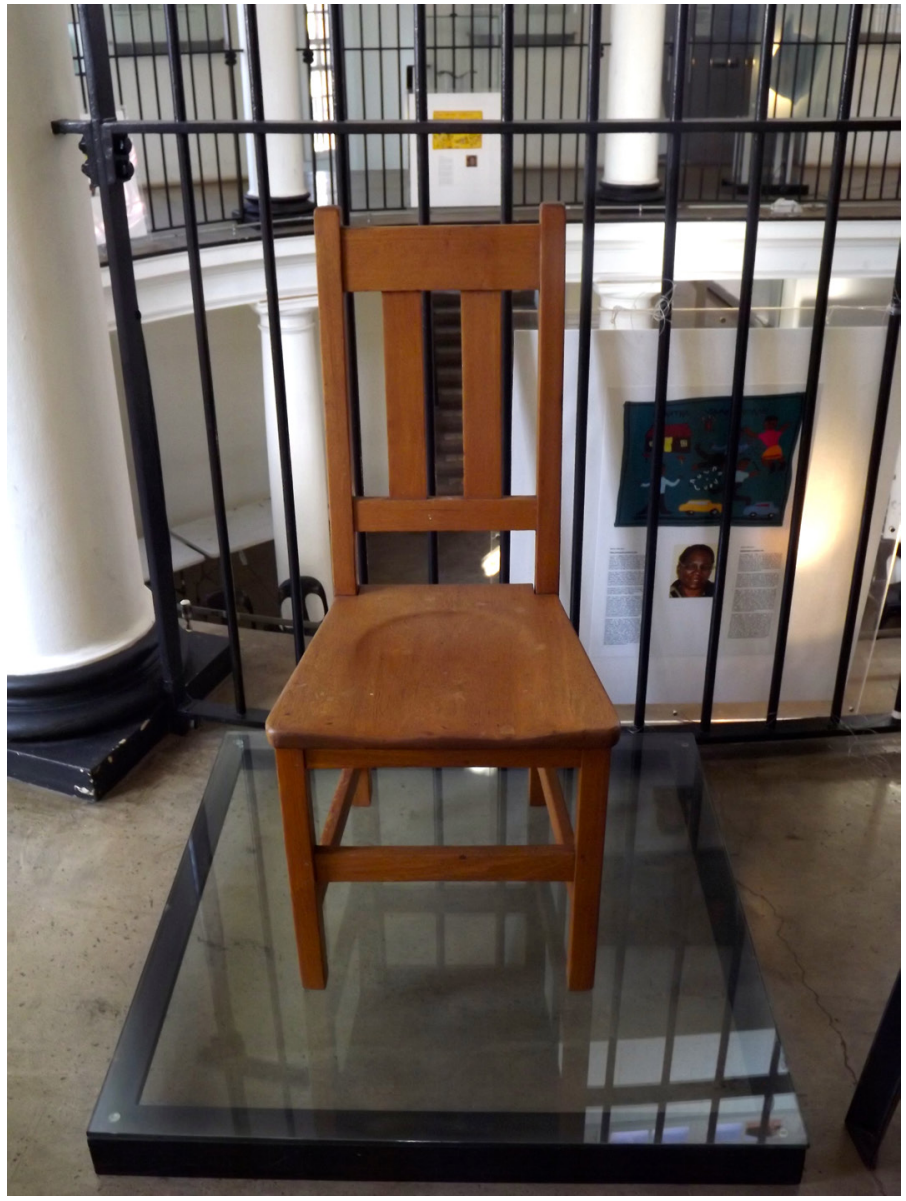

Fig 4. The Chair

Similarly, 'Prisoner Walls,' a painting by the prisoner, Fatima Meer, reproduces the memory of solidarity between Black wardress and Black prisoners. This painting shows a wardress and a prisoner playing a game together, despite rules against such interactions. Black wardresses, then, are portrayed as co-victims of apartheid and oppression in the Women's Jail. This rendering of apartheid memory, along with that of the chair installation, while not inaccurate, is only partial in its representation of co-victimhood and co-support among Black guards and prisoners. What is missing from this recreated and perhaps somewhat idealized narrative, are the power differences that also marked the social relations between Black prisoners and guards. Like their White counterparts, Black wardresses had complete control over the daily lives of Black prisoners, administering punishments and restricting their movements, rights and privileges. While the exhibits note that wardresses hit, kicked and routinely beat prisoners, the displays infer that these types of punishments were primarily carried out by White guards. The portrayal of Black guards as victims of apartheid in the prison system obscures the role that they also played in dehumanizing and terrorizing the women under their charge. Thus, within this space of racialized memory, the story of the Black wardress as perpetrator as well as victim remains untold. A comparison can be drawn with Holocaust memorials in which the actions of Jewish prisoners, particularly those who were given limited power within the death camp system, have rarely been commemorated at sites of Nazi terror where narratives of cruelty and punishment have tended to erase or suppress this painful reality of oppressive regimes (Perl 1993). As in Holocaust commemoration, the museum at Constitution Hill renders invisible the ways in which victims become perpetrators under conditions of control and dehumanization. 
Another memory that remains obscured within this museum space is the racial hierarchy of South African apartheid in which women of color who were not classified as Black were accorded special privileges. An important example of this aspect of racial privileging within the jail is illustrated by the museum's inclusion of the painting by the prisoner Fatima Meer that is described above. As an Indian woman, Meer was given access to paint and paper to which Black prisoners were denied. Thus, while a prisoner, she was able to create paintings of the Women's Jail and of life within the prison. Although her artwork is portrayed as an act of resistance (since documenting the prison was not permitted), her privileged racial status as an Indian woman within the apartheid regime is not acknowledged in the installation (Mdluli 2010), an omission that may have unintended consequences. Because no artwork of Black prisoners is similarly represented, the absence of textual references to racial hierarchy and racial privilege can lead to the false impression that Black prisoners were less creative and/or less resistant during their imprisonment. Taken together, the absence of both structural and racial hierarchical motifs contribute to the reproduction of 'partial memory,' a common attribute of memorialization that is also evident in the exclusion of women's violence and torture narratives within the commemorative space.

\section{Violence and Torture: The Missing Memories of Women Prisoners}

In the museum narratives of the Women's Jail, the documentation on torture and atrocity (for example, physical assault, sexual assault and electric shock) is sparse. Although such acts frequently took place while women were incarcerated (within and outside of the jail itself), these narratives have been excluded from the museum. As discussed previously, in the years following the end of apartheid, women's experiences were documented by former prisoners during workshops that were held as part of the Mapping Memory project (Coombes 2011; Segal, van den Berg and Madikida 2006). As participants in the creation of collective memories of apartheid, former women prisoners shared stories of their experiences with violent treatment in the jail and with torture while under arrest (though the torture often took place outside of the women's prison). Within the jail itself, the members of the workshop recounted their 'worst memories' in which they were physically abused by guards. One participant, Sibongile Tshabalala, offered this account:

My worst memory was when I was slapped across my face for not putting my hands behind me as I was entering the prison gate for the first time. I was a young 14-year old girl and I did not understand the prison rules, I was very shocked (Segal et al. 2006: 62)

Another former prisoner, Patricia Alarm, provided this memory of her incarceration:

My worst memory was when I was beaten up on the stairs going into section three. I have made my exhibition about this. I was beaten up because I stood up for a new inmate who stepped into the mbendeni (the haunted area) where we prisoners were not allowed. They broke my arm. I will never forget that. (Segal et al. 2006: 66)

In cases such as those cited above, the abuse was often followed by confinement in the isolation cells. Yet, these installation spaces do not focus on the violence within the jail but rather, as described earlier, create a memory of a social injustice or a lost civilian life. Thus, the cell exhibits, in representing the less traumatic narratives of imprisonment, obscure the more violent histories that were recorded in the Mapping Memory project and that have been published in a text, Mapping Memory: Former Prisoners Tell Their Stories (Segal, van den Berg, and Madikida 2006).

Similarly, the women's stories of torture and atrocities have also been excluded from other museum spaces, although they too were recounted in the memory workshops that have been published in the project's text. Through oral narratives and visual representations, the women recounted bodily violations, including sexual assault and the use of electric shock, during periods of torture and incarceration (Madikida et al. 2008: 21; Segal et al. 2006: 2). The 
introduction to the Mapping Memory book, written by the curators of the project, offers this insight into the use of art by workshop organizers to document the memories of traumatized participants:

Joyce Dipale, like many others, had been tortured at John Vorster Square. One day she asked one of the facilitators to draw the torture (see fig 1). She directed this drawing with great particularity, speaking determinedly as she explained the wall socket, the placement of electrodes, the black hood over her head. This confrontation through visualization seemed to mark a milestone for her, causing a re-living of the trauma as well as some degree of completion....this process made apparent once again the importance for each individual to confront the devils of their memory (Segal et al. 2006: 2).

This introductory description of the workshop process is illustrated with a drawing (figure 1 cited above) that graphically depicts the prisoner being shocked by electrodes that have been placed on her breasts. Thus, in comparison with the jail museum, the published text of the workshop makes visible the trauma memory of the victims and the atrocities to which women were subjected. Further, the men's prison on Constitution Hill, unlike the women's prison museum, graphically recalls these memories of brutality and violence. The absence of similar texts within the Women's Jail may therefore lead visitors to conclude that women were not treated as harshly, thus minimizing the history of women's suffering under apartheid.

In addressing the absence of atrocity narratives in the Women's Jail, Annie Coombes (2011) argues that the torture and atrocity memories that were collected at the workshops were purposely left vague in the museum because of the difficulty with which the former prisoners recalled these terrible events and the emotional strain of recollecting a violent past. At the same time, however, two years after the Women's Jail was opened, a number of prisoners formed an activist group, Sizoya Sibuye ('We Come Back'), to 'raise the profile' of the Women's Jail and to demand a less sanitized view of the prison where they were humiliated and abused. In critiquing the renovation of the Women's Jail museum, the activists point out that grass and flowers have replaced the dirt and concrete structures in which they were imprisoned and tormented (McAlister 2013; Serino 2007).

As these differing points of view suggest, former prisoners may have decidedly divergent views on the project of women's memorialization. In the case of the Women's Jail, it would appear that not all of these views have been represented. Further, the tensions that are evident in this memorial discourse are illustrative of the more universal challenges surrounding the memorialization of gendered violence. Recent studies of collective memory of genocide and mass rape have problematized the memorialization of crimes against women's bodies that put the victims at risk for stigma and shame in the aftermath of war (Helms 2007). Similarly, in portraying the humiliated and/or brutalized woman prisoner, the Women's Jail could put at risk the public memory of survivors whose traumatic pasts remain a source of emotional pain. Nevertheless, the exclusion of torture memory from the museum contributes to what others have identified as a collective silence surrounding the physical and sexual violation of women under apartheid (Graybill 2001: 6; McEwan 2003). The TRC, for example, was strongly criticized for focusing too narrowly on men's human rights violations while overlooking the particular experiences with torture and atrocity that women endured (Goldblatt and Meintjies 1996; Graybill 2001; Mgxashe 2000; Nytagodien and Neal 2004). In addition, the Commission was also criticized for considering women 'secondary' victims, important only in their relation to men who were the 'primary' victims of apartheid (Graybill 2001: 4). It was out of this criticism that the TRC eventually held special hearings on women, though many women were discouraged from testifying about gendered forms of torture, especially sexual assault and rape. The absence of their stories within the historical record and at the museum reflects the difficulties that women face both as memory keepers and as victims of apartheid trauma. In order to protect former prisoners from the pain and shame of the past, the Women's Jail museum has remained a space in which only partial truths are made visible within the collective memory of post-apartheid society. 


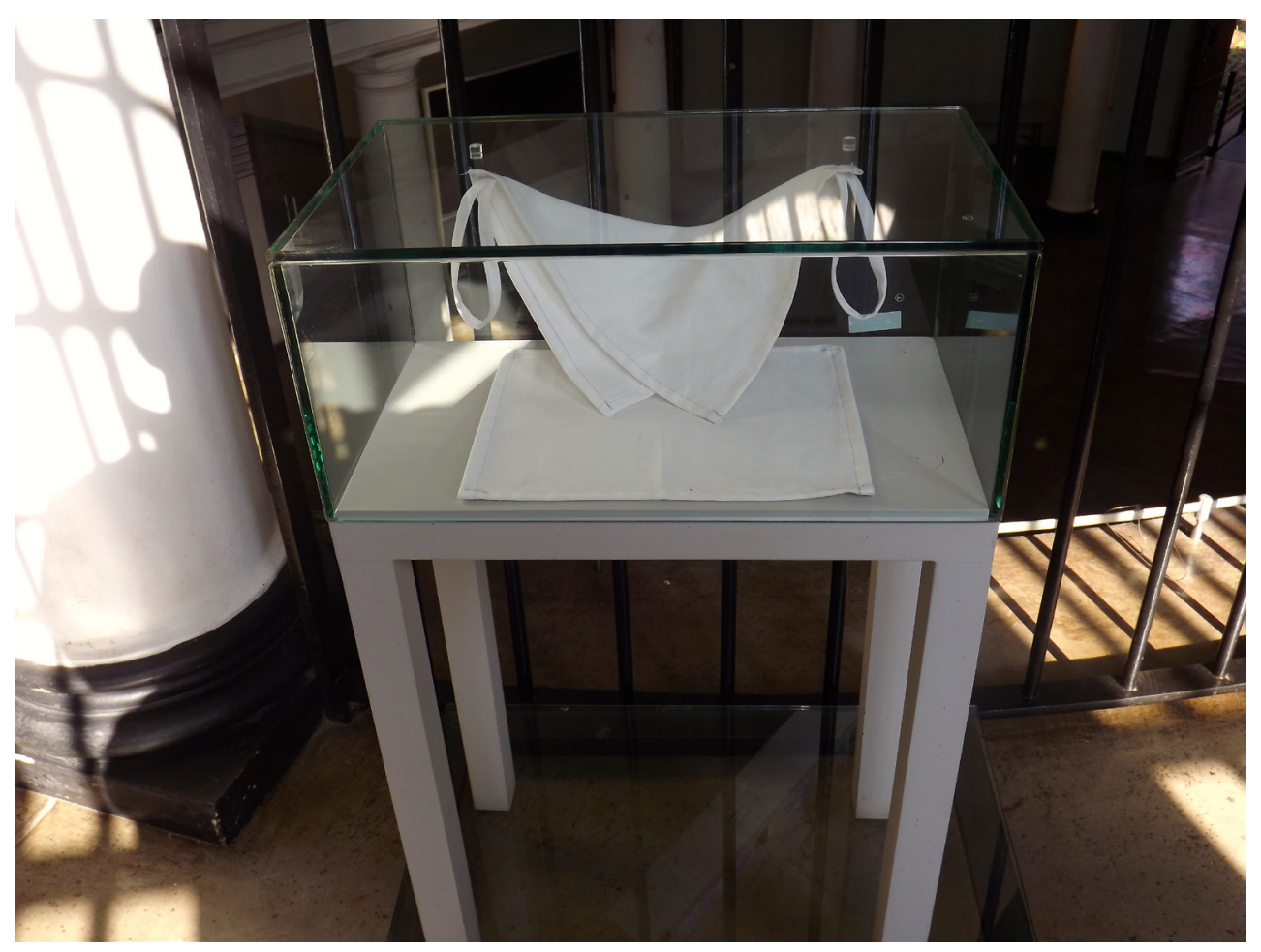

Fig 5. The Sanitary Pad

\section{Conclusion}

The overall findings of this research suggest that the motifs of remembrance that have been constructed around the Women's Jail focus on representations that both humanize and dehumanize the memory of imprisoned Black women. As our analysis has shown, the isolation cell exhibits give identity and dignity to the former political prisoners whose video-taped narratives and personal belongings help to create an empathic and humanizing bond between the visitor and the subject of memory. This effect of the isolation cell installations exists in contrast to the themes of humiliation and degradation that inform the menstruation-centered exhibits. In both streams of memory, however, the museum has effectively and poignantly used the artifacts of domesticity and prison life - a wedding dress, a chair, a sanitary pad, a shopping bag - to re-imagine a painful and persecutory past through the lens of 'ordinary' objects. The simplicity of the representations is itself a form of memory, invoking the lives of women whose every day acts of survival carried with them a threat of danger and arrest.

Further, as a model of curatorial inclusiveness, the construction of the Women's Jail and its relationship to the Mapping Memory Project offers insight into the creation of collective memory through a collaborative process that tells a particular story of apartheid and imprisonment. Within the diverse installations in the museum, this history has been represented through narratives, texts and visual images that in part are intended to protect the survivors from the re-traumatizing impact of the memorialization of terror. Thus, the fact that the museum does not delve more deeply into the history of gendered forms of abuse is explained by the curators as a response to the emotional needs of the former prisoners, the primary audience for whom the museum is intended (Segal et al. 2006). Yet, as this research has shown, former prisoners may have differing objectives that pose difficult challenges for national memorialization. As we look toward the future of remembrance, especially with respect to regimes of terror and violence, concerns around stigma, trauma and the cultural norms of gendered representation 
will continue to inform the ways in which women's experiences of suffering are either recalled or forgotten. Within the broader frame of the politics of memory, these concerns may also have the unintended consequences of repressing histories of violence against women while underrepresenting the significant role that women play in movements for social justice. With respect to South African memory in particular, the Women's Jail signifies both the presence and absence of memory and the tensions that underscore the memorialization of gendered forms of terror and political oppression.

Received: 17 March 2016 Finally Accepted: 3 July 2017

\section{Notes}

1 The initiators of the Mapping Memory project were the curators for the heritage site and museums at Constitution Hill. They collected historical artifacts, personal accounts, and lead workshops to understand the history of the jail. These workshops included both men and women and were intended "to ensure that the former prisoners played a key role in the development of the new heritage site" (Segal et al 2006: 1). Lauren Segal is the program Director at Constitution Hill. Clive van den Berg designed the museum at Constitution Hill and Churchill Madikida was the art facilitator and a curator for Constitution Hill's Mapping Memory project.

\section{References}

Biko, S. (2005) I write what I like, Cambridge: Cambridge University Press.

Coombes, A. (2003) History After Apartheid: Visual Culture and Public Memory in a Democratic South Africa, Durham: Duke University Press.

(2011) 'Witnessing history/embodying testimony: gender ad memory in post-apartheid South Africa', Journal of the Royal Anthropological Institute, S92-S112.

Crysler, C. G. (2006) 'Violence and Empathy: National Museums and the Spectacle of Society', TDSR, 17 (2) 19-38.

Derrida, J. (1985) 'Racism's Last Word', Critical Inquiry, 12 (1) 290-299.

Du Toit, L. (2016) 'The South African Constitution as Memory and Promise: An Exploration of its Implications for Sexual Violence', Politikon 43 (1) 31-51.

Emerson, R, Fretz, R and Shaw, L. (1995) Writing Ethnographic Fieldnotes, Chicago, IL: The University of Chicago Press.

Gevisser, M. and Nuttall, S. (2004) 'From the Ruins: The Constitution Hill Project', Public Culture, 16 (3) 507-519.

Gibson, J. (2004) 'Overcoming Apartheid: Can Truth Reconcile a Divided Nation?', Politikon, 31 (2) 129-155.

Goldblatt, B. and Meintjies, S. (1996) Gender and the Truth and Reconciliation Commission: A submission to the Truth and Reconciliation Commission, Cape Town: Juta Publishing.

Graybill, L. (2001) 'The Contribution of the Truth and Reconciliation Commissions toward the Promotion of Women's Rights in South Africa', Women's Studies International Forum, 24 (1) 1-10. 
Helms, E. (2007) '"Politics is a whore": Women, Morality and Victimhood in post-war Bosnia-Herzegovina', in X. Bougarel, E. Helms, and G. Duijzings (eds) The New Bosnian Mosaic: Identities, Memories and Moral Claims in a Post-War Society, 235253, Burlington, VT: Ashgate Publishing Company.

Hook, D. (2011) A Critical Psychology of the Postcolonial: The Mind of Apartheid, London: Routledge.

Jacobs, J. (2010) Memorializing the Holocaust: Gender, Genocide and Collective Memory, London: I. B. Tauris.

King, T. and Flynn, M. (2012) 'Heritage and Post-Apartheid City: Constitution Hill Johannesburg', International Journal of Heritage Sites, 18 (1) 65-82.

Koorts, L. (2013) '"The Black Peril would not exist if it were not for a White Peril that is a hundred times greater": D.F. Malan's Fluidity on Poor Whiteism and Race in the PreApartheid Era, 1912-1939', South African Historical Journal, 65 (4) 555-576.

Lofland, J., Snow, D., Anderson L., and Lofland, L. (2006) Analyzing Social Settings: A Guide to Qualitative Observation and Analysis, Australia: Thomson Wadsworth.

Longair, S. (2013) 'Unlocking the Doors of Number Four Prions: Curating the Violent Past in Contemporary South Africa', in Lizeele Bisschoff and Stefanie Van De Peer (eds) Art and Trauma in Africa, 110-130, New York: Palgrave Macmillan.

Madikida, C, Segal, L. and Van Den Berg, C. (2008) 'The Reconstruction of Memory at Constitution Hill', The Public Historian, 30 (1) 17-25.

McAllster, J. (2013) 'Collecting the Gaze: Memory, Agency, and Kinship in the Women's Jail Museum, Johannesburg', Women's Studies in Communication, 36 1-27.

Mdluli, S. (2010) 'Paintings and Drawings of Fatima Meer in the context of the struggle narrative at Constitution Hill', Wits Institutional Repository Electronic Theses and Dissertations http://wiredspace.wits.ac.za/handle/10539/8869 accessed 15 October 2016.

McEachern, C. (1998) 'Mapping the Memories: Politics, Place and Identity in the District Six Museum, Cape Town', in Abebe Zegeye (ed) Social Identities in the New South Africa, 223-247, Cape Town: Kwela Books.

McEwan, C. (2003) 'Building a Postcolonial Archive? Gender, Collective Memory and Citizenship in South Africa,' Journal of Southern African Studies, 29 (3) 739-757.

Mgxashe, M. (2000) 'Reconciliation: a call to action', in C. Villa-Vicencio and W. Verwoerd (eds) Looking back, reaching forward: reflections on the Truth and Reconciliation Commission of South Africa, 210-18. Cape Town: University of Cape Town Press.

Miller, K. (2011) 'Selective Silence and the Shaping of Memory in Post-Apartheid Visual Culture: The Case of the Monument to the Women of South Africa', South African Historical Journal, 63 (2) 295-317.

More, M. (2014) 'Locating Frantz Fanon in Post-Apartheid South Africa', Journal of Asian and African Studies, 49 (6) 1-15.

Motsemme, N. (2002) 'Gendered Experiences of Blackness in Post-Apartheid South Africa', Social Identities, 8 (4) 647-673. 
Nanda, S. (2004) 'South African Museums and the Creation of a New National Identity', American Anthropology, 106 (2) 379-385.

Nytagodien, R. and Neal, A. (2004) 'Confronting an Ugly Past', The Journal of American Culture, 27 (4) 375-383.

Olick, J. K., Vinitzky-Seroussi, V. and Levy, D. (eds) (2011) The Collective Memory Reader, Oxford: Oxford University Press.

Perl, Gisella. (1993) 'A Doctor at Auschwitz', in C. Rittner and J. Roth (eds) Women and the Holocaust: Different Voices, 104-118, New York: Paragon House.

Pogrund, B. (2000) War of Words: Memoir of a South African Journalist, New York: Seven Stories Press.

Posel, D. (2010) 'Races to Consume: revisiting South Africa's History of Race, Consumption and the Struggle for Freedom', Ethnic and Racial Studies, 33 (2) 157-175.

Ranken, J. (1997) 'Testimony of Joyce Ranken' Truth and Reconciliation Commission Human Rights Violations Women's Hearing. http://www.justice.gov.za/trc/special/ women/ranken.htm accessed 15 October 2016.

Ringelheim, J.M. (1997) 'Genocide and gender: a split memory', in R. Lentin (ed) Gender and Catastrophe, London: Zed Books.

Segal, L, Van Den Berg, C. and Madikida, C. (2006) Mapping Memory: Former Prisoners Tell their Stories, Parkwood, South Africa.

Serino, T. K. (2007), 'Bring Back Our Number Four', Business Day [Johannesburg], Weekender ed., opinion and editorial, 1 January 2007. page 5.

Simigiannis, R. (2012) 'Do Memory Initiatives Have a Role in Addressing Cultures of Silence that Perpetuate Impunity in South Africa'? Impunity Watch. http://www. impunitywatch.org/docs/SouthAfrica_Mem_Research_Report.pdf accessed 15 October 2016.

Tihanyi, K. (2007) 'Racial integration in the USA and South Africa: Lessons in a comparative perspective', International Journal of Inclusive Education, 11 (2) 177-197.

Van Der Watt, L. (2005) 'Witnessing Trauma in Post-Apartheid South Africa: The Question of Generational Responsibility', African Arts, 38 (3) 26-35.

Van der Merwe, C. D. (2013) 'The limits of Urban Heritage Tourism in South Africa: The Case of Constitution Hill, Johannesburg', Urban Forum 24, 573-588.

Waetjen, T. (1999) 'The "Home" in Homeland: Gender, National Space, and Inkatha's Politics of Ethnicity', Ethnic and Racial Studies, 22 (4) 653-678.

Williams, R. (2015) Seeing religion: Toward a Visual Sociology of Religion, New York: Routledge.

Young, J. (1993) The Texture of Memory: Holocaust Memorials and Meanings, New Haven: Yale University Press. 
*Stephanie Bonnes is a doctoral candidate in the Department of Sociology at the University of Colorado, Boulder. Her research focuses on violence against women perpetrated at the interpersonal, organizational, and state level, gendered representations of violence, and identities. She has a master's degree in International Studies from Rhodes University in South Africa.

Stephanie Bonnes

University of Colorado, Boulder

UCB 327 Ketchum 195

Boulder, CO 80309

856-381-6323

Stephanie.bonnes@colorado.edu

** Janet Jacobs is Professor of Sociology and Women and Gender Studies at the University of Colorado. Her research focuses on ethnic and religious violence, gender, mass trauma, and collective memory. She is author of numerous books and journal articles, including Memorializing the Holocaust: Gender, Genocide and Collective Memory (2010) and The Holocaust Across Generations: Trauma and Its Inheritance Among Descendants of Survivors (forthcoming 2016). Her current work is on genocide and collective memory in Bosnia-Herzegovina.

Janet Jacobs

University of Colorado, Boulder

UCB 246;

Boulder, CO 80309

3034923202

jacobsj|@colorado.edu 